\title{
T-cell and macrophage subsets in the bronchial wall of clinically healthy subjects
}

\author{
C.K. Power*, C.M. Burke*, S. Sreenan*, B. Hurson*, L.W. Poulter**
}

T-cell and macrophage subsets in the bronchial wall of clinically healthy subjects. C.K. Power, C.M. Burke, S. Sreenan, B. Hurson, L.W. Poulter. CERS Journals Ltd 1994.

ABSTRACT: This study was conducted to obtain quantitative data on the numbers of $T$-cells and macrophage subsets in the normal bronchial wall of man, and, thus, produce a baseline against which the numbers of these cells present in inflamed bronchi may be judged.

Bronchial biopsies were obtained from 27 clinically healthy subjects attending hospital for elective orthopaedic operations. Eight of the subjects were smokers (median 3.5 pack-years), and eight were atopic as defined by skin prick test. Three to eight weeks after biopsy, subjects attended the lung function laboratory for spirometric testing and determination of provocative concentration of histamine producing a $20 \%$ fall in forced expiratory volume in one second $\left(\mathrm{PC}_{20} \mathrm{FEV}_{1}\right)$. The bronchial biopsies were frozen and cryostat sections prepared. These sections were investigated with immunohistological techniques to reveal the presence and distribution of $T$-cell and macrophage subsets.

Twenty six out of 27 subjects had spirometric values within the normal range, but a wide spectrum of bronchial reactivity was observed $\left(\mathrm{PC}_{20} \mathrm{FEV}_{1}\right.$ range 2-36 $\mathrm{mg}$ histamine). Using monoclonal antibodies in immunohistological techniques, only small numbers of T-cells were seen, the majority being CD8+ cells in the epithelium. In the underlying tissue, CD4+ cells predominated (CD4/CD8 ratio, epithelium 1:9; underlying tissue 4:1). In both cases, approx. $50 \%$ of T-cells expressed the CD45Ro isotype. Small numbers of macrophages were observed in all samples. The majority of these cells expressed a "suppressor cell" phenotype (RFD1+RFD7+), whilst only a small proportion (median 11\%) exhibited the phenotype of antigen presenting cells (RFD1+RFD7-). Only very low levels of human leucocyte antigenDR (HLA-DR) were recorded, both on the epithelium and underlying tissues. Smoking status and atopy did not influence the numbers and distribution of the $T$ cells and macrophages.

These data offer, for the first time, a baseline against which the severity of immunopathological reactions in the bronchial wall may be evaluated.

Eur Respir J., 1994, 7, 437-441.

\begin{abstract}
*Dept of Respiratory Medicine, James Connolly Memorial Hospital, Dublin, Eire. **Dept of Clinical Immunology, Royal Free Hospital School of Medicine, London, UK.
\end{abstract}

Correspondence: L.W. Poulter Dept Clinical Immunology

Royal Free Hospital School of Medicine Pond Street

Hampstead

London NW3 2QG

UK

Keywords: Bronchial wall

macrophages

normals

T-cells

Received: March 231993

Accepted after revision October 31993

This work was supported by MRC grant SPG8910613 to L.W.P.
The distribution of T-cell and macrophage subsets in the bronchial tissue of clinically healthy subjects has not yet been documented. With an increasing interest in the tissue immunopathology of diseases involving bronchial inflammation, a need clearly exists for this information. Studies of such diseases as asthma and bronchiectasis [1, 2], have identified abnormalities of T-lymphocyte and macrophage subsets in terms of the tissue distribution of these cells [3], cell activation [4], and even clonal changes caused by dysregulation of T-cell stimulation [5]. It is important, therefore, to establish the disposition of these cells in tissues from clinically healthy subjects, so that a clear baseline can he obtained against which any degree of abnormality in diseased tissues may be judged. Studies in rodents have identified the presence of $\mathrm{T}$-cell and macrophage subsets in normal bronchial tissues [6, 7], and extensive investigation of the interaction of these cells has led to the conclusion that antigenic stimulation of T-cells may be regulated by the balance between inducer and suppressor macrophages [8, 9].

The present study has used immunohistological techniques and image analysis to quantify the distribution of lymphocyte and macrophage subsets in the bronchial wall of 27 clinically healthy subjects.

\section{Subjects and methods}

Twenty seven subjects undergoing general anaesthesia for routine knee arthroscopy gave informed written consent for a perioperative fibreoptic bronchoscopy and endobronchial biopsy. The study was approved, as part of an ongoing fibreoptic bronchoscopy protocol in asthma, by the James Connolly Memorial Hospital Ethics 
Committee. Subjects were recruited on the basis of a medical history devoid of any chronic illness, medical hospitalizations, or current medical symptoms (on full systems review). No subjects had had any viral illness in the two months prior to the study and none had ever consulted a physician for a chest problem.

Eight subjects were smokers (median 3.5 pack-years, range 1-15 pack-years). Eight subjects were atopic (responding to one or more prick test allergens from a panel of grass pollen, tree mix, house dust, house dust mite, cat, dog and feather; Dome Hollister Stier).

\section{Bronchoscopy}

General anaesthesia was induced with intravenous thiopentone, $3-5 \mathrm{mg} \cdot \mathrm{kg}^{-1}$, and maintained with a mixture of oxygen, nitrous oxide and ethane. Each patient was intubated using a disposable size 9 endotracheal tube (ET). Intubating conditions were achieved with suxamethonium, $1-1.5 \mathrm{mg} \cdot \mathrm{kg}^{-1}$, and perioperative muscle relaxation was maintained with vecuronium, titrated to effect. Perioperative analgesia was provided as fentanyl, 1-1.5 $\mu \mathrm{g} \cdot \mathrm{kg}^{-1}$. Standard monitoring included electrocardiographic (ECG) trace, automated blood pressure cuff and pulse oximetry. Under the supervision of the anaesthetist, the bronchoscopist passed the fibreoptic bronchoscope, (Olympus BF10), through the ET tube into the trachea. The right upper lobe carina was identified and, adjacent to this, endobronchial biopsies were taken under direct vision, using cupped spiked forceps. Up to three biopsies were removed from each subject.

\section{Sample preparation}

Immediately after collection, biopsies were placed in cryo-embed medium (Brights Instrument Co. Huntingdon, UK) on a small cork disc, and snap frozen in isopentane cooled in a bath of liquid nitrogen. Six micron sections were cut on a cryostat maintained below $-25^{\circ} \mathrm{C}$. These were air dried, fixed in chloroform acetone (1:1), wrapped in cling film and stored at $-20^{\circ} \mathrm{C}$ until used.

\section{Histology}

Sections from all samples (a total of 40 biopsies) were stained with $0.1 \%$ toluidine blue to reveal morphology and tissue integrity.

\section{Immunohistology}

Indirect immunoperoxidase methods [10], were utilized to identify individual lymphocyte and macrophage subsets. The monoclonal antibodies (MoAbs) used are listed in table 1. CD4:CD8 ratios and relative proportions of macrophage subsets were determined using double immunofluorescence methods, in which two MoAbs of different class (immunoglobulin $\mathrm{M}$ and $\mathrm{G}$ (IgM and $\operatorname{IgG})$ ) were used together as a first layer and the second layer contained a mixture of affinity purified goat anti mouse IgM, (conjugated to fluorescein isothiocyanate (FITC)), and goat anti mouse IgG, (conjugated to tetra ethyl rhodamine isothiocyanate (TRITC)), both from Southern Biological Associates, (Alabama, USA), [17]. All staining reactions were accompanied by negative controls, omitting the primary layer MoAbs, and positive controls, using sections of human palatine tonsil. All immunoperoxidase preparations were counterstained with haematoxylin, with the exception of human leucocyte antigen-DR (HLA-DR) staining which was left without counterstain to allow quantitation of reaction product (see below).

\section{Lung function}

After a postoperative period of at least 3 weeks, but within 8 weeks, biopsied subjects attended the lung function laboratory for spirometric testing and a bronchial challenge test to inhaled histamine. Baseline spirometry was recorded using a Gould 2400 computerized system. These tests were followed by determination of the provocative concentration of histamine producing a $20 \%$ fall in forced expiratory volume in one second $\left(\mathrm{PC}_{20} \mathrm{FEV}_{1}\right)$ using a standard bronchial challenge protocol

Table 1. - Monoclonal antibodies used in this study

\begin{tabular}{|c|c|c|c|c|c|}
\hline Reagent & CD No. & $\begin{array}{l}\text { MW } \\
\text { kDa }\end{array}$ & Ig class & $\begin{array}{l}\text { Specificity in } \\
\text { normal tissues }\end{array}$ & [Ref.] \\
\hline T-mix & $2,5,8$ & $50,67,33$ & IgG/IgM & All T-lymphocytes & [11] \\
\hline B-mix & 19,20 & 95,35 & $\mathrm{IgG}$ & All B-cells & [12] \\
\hline RFT4 & 4 & 59 & IgG & T-cell subset & [11] \\
\hline RFT8 & 8 & 33 & $\operatorname{IgM}$ & $\mathrm{T}$-cell subset & [11] \\
\hline UCHL1 & 45Ro & 180 & $\mathrm{IgG}$ & Memory T-cells & [13] \\
\hline EBMII & 68 & 110 & IgG & All macrophages & [14] \\
\hline RFD7 & - & 77 & $\mathrm{IgG}$ & Macrophage subset & [15] \\
\hline RFD1 & - & $28-33$ & $\operatorname{IgM}$ & $\begin{array}{l}\text { Epitope on Class II } \\
\text { MHC, dendritic } \\
\text { cells/some B-cells }\end{array}$ & [15] \\
\hline RFDR1 & - & $28-33$ & $\operatorname{IgM}$ & $\begin{array}{l}\text { Framework epitope } \\
\text { on HLA-DR }\end{array}$ & [16] \\
\hline
\end{tabular}

Ig: immunoglobulin; MHC: major histocompatibility complex; HLA-DR: human leucocyte antigen-DR. CD: Cluster of Differentiation. 
[18]. $\mathrm{FEV}_{1}$ was measured after 2 min inhalation of nebulized saline. This measurement was repeated after inhalation of graded doubling concentrations of histamine, starting with $0.03 \mathrm{mg} \cdot \mathrm{ml}^{-1}$, delivered by a Hudson nebulizer driven by oxygen at a rate of $7 l \cdot \mathrm{min}^{-1}$. After each concentration of histamine, $\mathrm{FEV}_{1}$ was recorded at 30 and $90 \mathrm{~s}$. If no drop of $\mathrm{FEV}_{1}$ occurred, the next concentration was then applied. When the concentration of histamine used caused a $>20 \%$ drop in $\mathrm{FEV}_{1}$ the test was terminated and $\mathrm{PC}_{20} \mathrm{FEV}_{1}$ calculated by regression analysis from the dose response curve.

\section{Quantification of the immunohistology}

The presence and distribution of immunocompetent cells was assessed and quantified using a computerized image analysis system (Seescan Cambridge) [19]. Peroxidase labelled cells were point counted in frame defined areas of the tissue sections. The size of the framed area was recorded, and the numbers of positive cells calculated per unit area of tissue. Three areas each of epithelium and subepithelial connective tissue were quantified in each section. In total, an area of $8-12.5 \times 10^{4} \mu^{2}$ was quantified on duplicate sections from one sample of each subject. Damaged areas and areas of muscle or cartilage were avoided when frames were drawn with the computer. Median figures for the incidence of each cell subset were calculated. Data are presented as median and range for the whole group.

Level of expression of HLA-DR was measured as optical density of reaction product. In each subject, the optical density of the reaction product in the stained section was measured with the image analyser in 6-10 marked fields selected at random both along the epithelium and in the subepithelial connective tissue. This process was first performed for each sample on sections incubated without MoAb (negative controls), and then on the test section. The difference in optical density between these two readings was taken as the relative absorption of the reaction product resulting from the expression of HLADR. Thus, background staining was eliminated by subtracting these figures from those obtained when specific MoAbs were used. CD4:CD8 ratios and proportions of macrophage subsets were calculated by counting positive cells in high power fields, using a Zeiss fluorescence microscope fitted with epi-illumination and barrier filters for FITC and TRITC.

Proportions of macrophage subsets were calculated by the formula:

$$
\frac{\text { Number of specific subset } \times 100}{(\text { RFD1+ })+(\text { RFD7+ })+(\text { RFD1+RFD7+ })}
$$

\section{Results}

\section{Lung function}

Twenty six out of 27 subjects exhibited spirometric values within the predicted range. One subject had low
Table 2. - Lung function data on 27 clinically healthy subjects

\begin{tabular}{lrl}
\hline & Median & \multicolumn{1}{c}{ Range } \\
\hline $\mathrm{FEV}_{1} \%$ pred & 100 & $(67-129)$ \\
$\mathrm{FVC}_{\%} \%$ pred & 103 & $(71-129)$ \\
$\mathrm{FEV}_{1} / \mathrm{FVC} \%$ & 81 & $(79-99)$ \\
$\mathrm{FEF}_{25-75} \%$ pred & 97 & $(57-127)$ \\
$\mathrm{PC}_{20} \mathrm{FEV}_{1} \mathrm{mg} \cdot \mathrm{ml}^{-1}$ & 12.5 & $(2-36)$
\end{tabular}

$\mathrm{FEV}_{1}$ : forced expiratory volume in one second; FVC: forced vital capacity; $\mathrm{FEF}_{25-75}$ : forced mid-expiratory flow; $\mathrm{PC}_{20} \mathrm{FEV}_{1}$ : provocative dose of histamine producing a $20 \%$ fall in $\mathrm{FEV}_{1}$.

$\mathrm{FEV}_{1}$ and forced mid-expiratory flow $\left(\mathrm{FEF}_{25-75}\right)$. This individual, however, satisfied all criteria as clinically healthy and all other parameters measured showed no inconsistency with the group as a whole. A broad range of bronchial reactivity was recorded on the histamine challenge test. $\mathrm{PC}_{20} \mathrm{FEV}_{1}$ varied from 2-36 mg. Nine subjects exhibited a $\mathrm{PC}_{20} \mathrm{FEV}_{1}$ of $<8 \mathrm{mg}$. However, when compared to the other 18 subjects, no difference in spirometry was observed [20]. Medians and ranges for all parameters are presented in table 2 .

\section{Histology}

Sections from these biopsies were small, ranging 1-5 $\mathrm{mm}^{2}$. Samples showing no epithelium were not used. All samples analysed exhibited normal histology, with an epithelial layer supported by loose connective tissue containing small blood vessels. Some specimens showed some disruption to the epithelium, but this was taken to be artefactual, resulting from biopsy and cryostat sectioning technique. No thickening was observed below the epithelium on any specimen. All biopsies (40 samples) were examined histologically. No significant difference was seen between the duplicate samples taken from individual subjects, or between smokers and nonsmokers (see below).

\section{Immunohistology}

Lymphocytes. No B-lymphocytes were identified in any of the samples. Small numbers of T-cells were observed in 25 out of 27 samples. These cells were consistently greater in number in the epithelium than in the supporting connective tissue (lamina propria) (table 3). Both in the epithelium and the underlying lamina propria a proportion of the T-cells were CD45Ro+. This proportion was greater in the underlying tissue, than in the epithelium.

Double immunofluorescence analysis revealed that almost all the T-cells in the epithelium were CD8+ (median ratio 1:9), whilst in the lamina propria CD4+ cells were in the majority, (median ratio 4:1). In 10 out of 27 samples, however, insufficient $(<10$ in total or one population absent) cells were present to determine an accurate ratio of CD4:CD8 T-cells, even when the whole section was examined. 
Table 3. - T-cell subsets in the bronchial wall of clinically healthy subjects

\begin{tabular}{|c|c|c|c|}
\hline & $\begin{array}{l}\text { Total T-cells } \\
\quad n=27\end{array}$ & $\begin{array}{c}\text { CD45Ro+ T-cells } \\
n=27\end{array}$ & $\begin{array}{c}\text { CD4:CD8 ratio } \\
n=17\end{array}$ \\
\hline Epithelium & $2.4 \quad(0-5.7)$ & $0.48 \quad(0-26)$ & $1: 9 \quad(1: 5-1: 10)$ \\
\hline Lamina propria & $0.98(0-3.3)$ & $0.65 \quad(0-4)$ & $4: 1 \quad(1: 1-6: 1)$ \\
\hline
\end{tabular}

Data are presented as median, and range in parenthesis. All data represent cells per $10^{-4} \mu^{2}$.

Table 4. - Macrophages in the bronchial wall of clinically healthy subjects

\begin{tabular}{cccccc}
\hline & & & \multicolumn{3}{c}{ MQ subsets (n=14) } \\
\cline { 3 - 6 } CD68+ & RFD1+ & RFD7+ & \multicolumn{2}{c}{$\begin{array}{c}\text { D1+D7- D7+D1- D7+D1+ } \\
\%\end{array}$} & $\%$ \\
\hline 1.2 & 0.3 & 0.2 & 11 & 44 & 46 \\
$(0.5-5.2)$ & $(0-2.8)$ & $(0-3.2)$ & $(3-19)$ & $(17-65)$ & $(27-75)$
\end{tabular}

Data are presented as median, and range in parenthesis. MQ $=$ Macrophage.

Macrophages. Small numbers of macrophages were identified with the MoAb CD68 in all samples studied (table 4). These were distributed predominantly in the supporting connective tissue. Very few CD68+ cells were seen in the epithelium and, thus, no distinction was made between these two areas when point counts of cells were made. Immunoperoxidase staining with the MoAbs, RFD1 and RFD7, revealed a wide variation between sections, with some samples showing no positive cells, (table 4). Fourteen samples where both RFD1+ and RFD7+ cells were seen were further analysed with double immunofluorescence. This revealed that the RFD1+ RFD7- cells (antigen presenting cells) constituted only a minor population, whilst large proportions of RFD7+ RFD1- (mature phagocytes) and RFD7+RFD1+ (suppressor macrophages) were seen (table 4 ).

HLA-DR expression. Measurement of optical density of reaction product following immunoperoxidase staining offers a semiquantitative measure of antigen expression (see methods) [19]. Using this approach it was revealed that very low levels of HLA-DR antigen were expressed by the epithelial cells of the bronchi, and by cells in the supporting connective tissue. This reactivity was so low, however, that it was not possible to determine which cells within the connective tissue were positive. Figures are presented in table 5 .

Table 5. - HLA-DR expression in the bronchial wall of clinically healthy subjects

\begin{tabular}{lcc}
\hline & Epithelium & Lamina propria \\
\hline HLA-DR-relative absorption & $\begin{array}{c}0.04 \\
(0-0.17)\end{array}$ & $\begin{array}{c}0.03 \\
(0-0.14)\end{array}$
\end{tabular}

Data are presented as mean, and range in parenthesis. HLADR: human leucocyte antigen-DR.
The effect of smoking status and atopy. Comparison of the above parameters in smokers and nonsmokers within the original group revealed no significant difference. This was also true of atopic status (data not shown).

\section{Discussion}

This study reveals, for the first time, the incidence of $\mathrm{T}$-cell and macrophage subsets in the bronchial mucosa of clinically healthy individuals, together with the level of expression of HLA-DR. Such data now make it possible to gauge the extent of the infiltration by these cells in tissues studied from subjects with disease [1-2]. Such a comparison reveals that the figures quoted previously for asthma $[19,21]$ represent a tenfold or greater increase over the normal values recorded in the present study.

Our results show that in healthy tissues these cell types are sufficiently sparse as to be absent on isolated sections from some samples. There is clearly a possibility of sampling error in analysis of 1-2 sections from biopsies taken at a single site in an organ the size of the lung. However, ethical reasons prohibit the taking of multiple samples from clinically healthy subjects, and other published studies of bronchial biopsies from diseased tissues have also been restricted to 1-2 samples [21]. Nevertheless, caution should be exerted in interpretation, as, for example, no follicles of bronchus associated lymphoid tissue were observed in these bronchoscopic biopsies, whilst histological studies of postmortem or resection biopsies have identified such structures [22]. The sparsity of T-cells (particularly CD45Ro+ cells) in the bronchial wall, and the relatively dominant proportion of macrophages with suppressor phenotype (RFD1+ RFD7+) over those with inducer phenotype (RFD1+ RFD7-), suggest that the clinically healthy lung is not designed to respond aggressively to antigenic stimulus; this suggestion is in keeping with an increasing body of evidence that acquired T-cell responses are actively downregulated in the bronchial tree [8, 23, 24].

It should be noted that these biopsies were taken under general anaesthesia, whilst previous studies of pathological tissue have been performed on samples taken under mild sedation [3]. It is not known whether this difference might affect the results. It is difficult to imagine, however, that gross changes to the cellularity of the bronchial wall would occur in the brief time that these subjects had been anaesthetized. Furthermore, the results reported are broadly in line with control data obtained previously, when samples were acquired under sedation from patients bronchoscoped for single episodes of haemoptysis and no clinical abnormalities were observed [3].

The observation that no significant change in T-cell and macrophage subsets is associated with smoking history is interesting. Other studies have revealed changes in the bronchoalveolar lavage (BAL) fluid of smokers [25]. Thus, our observations suggest that such changes may be restricted to the airways and are not reflected in the tissues. This observation is also in line with the thinking that BAL predominantly samples the peripheral 
airways, rather than the bronchi. Indeed, even when comparisons are made between BAL and transbronchial biopsy, similar types of cells are seen but no quantitative correlation in terms of cellularity is observed [26]. Those subjects that exhibited $\mathrm{PC}_{20} \mathrm{FEV}_{1}$ of $<8 \mathrm{mg}$ showed normal spirometry (see results). However, a separate analysis of this group [20] failed to demonstrate any increase in the presence of $\mathrm{T}$-cell and macrophage subsets. Thus, we suggest that the data reported here offer an invaluable baseline against which the severity of inflammation in pathological samples already documented $[1,3,19]$, and the efficacy of therapy reported previously [21], might be judged.

Acknowledgements: The authors are grateful to B. Hurson for allowing them to use his patients and to the patients themselves. The authors acknowledge the technical assistance of A. Condez and S. Doyle, as well as the support of the Eastern Health Board, Dublin.

\section{References}

1. Poulter LW, Power C, Hutter C, Sreenan S, Burke C. T-cells and other mononuclear cells in asthma. In: Kummer F, ed. Asthma: Immunopathology, Immunotherapy. Wien New York, Springer Verlag, 1993; pp. $1-11$.

2. Lapa e Silva JR, Jones A, Cole PJ, Poulter LW. The immunological component of the cellular inflammatory infiltrate in bronchiectasis. Thorax 1989; 44: 668-673.

3. Poulter LW, Power C, Burke C. The relationship between bronchial immunopathology and hyperresponsiveness in asthma. Eur Respir J 1990; 3: 792-799.

4. Kay AB, Corrigan CJ, Frew AJ. The role of cellular immunity in asthma. Eur Respir J 1991; 4 (Suppl. 13): 103-112.

5. Wierenga EA, Snoek M, Degroot C, et al. Evidence for compartmentalization of functional subsets of CD4+ T-lymphocytes in atopic patients. J Immunol 1990; 144: 4651-4656.

6. Holt PG, Schon MA, Oliver J. MHC Class II antigen bearing dendritic cells in pulmonary tissues of the rat, regulation, presentation activity by endogenous macrophage populations. J Exp Med 1988; 167: 262-270.

7. Seimecka JW, Davis JK, Cassell GH. Distribution of Ia antigens and T-lymphocyte subpopulations in rat lungs. Immunology 1986; 57: 93-98.

8. Holt PG, McMenamin C, Schon-Hegrad MA, et al. Immunoregulation of asthma: control of T-lymphocyte activation in the respiratory tract. Eur Respir J 1991; 4 (Suppl. 13): 6-15.

9. Holt PG. Macrophage dendritic cell interaction in regulation of the IgE response in asthma. Clin Exp Allergy 1993; 23: 4-6.

10. Campbell D, Poulter LW, Janossy G, du Bois RM. Immunohistological analysis of lung tissue from patients with cryptogenic fibrosing alveolitis suggests local expression of immune hypersensitivity. Thorax 1985; 40: 405-411.
11. Janossy G, Prentice HG. T-cell subpopulations, monoclonal antibodies and their therapeutic applications. Clin Haematol 1982; 11: 631-661.

12. Collings LA, Poulter LW, Janossy G. The demonstration of cell surface antigens on T-cells, B-cells and accessory cells in paraffin embedded tissues. J Immunol Methods 1984; 75: 227-239.

13. Akbar A, Terry L, Timms A, Beverly PCL, Janossy G. Loss of CD45Ra and gain of UCHL1 reactivity is a feature of primed T-cells. J Immunol 1988; 140: 1-8.

14. Kelly PMA, Bliss E, Morton JA, Burns J, McGee JD. Monoclonal antibody EBMII in cellular specificity for human macrophages. J Clin Pathol 1988; 41: 510-515.

15. Poulter LW, Campbell DA, Munro C, Janossy G. Discrimination of human macrophages and dendritic cells using monoclonal antibodies. Scand J Immunol 1986; 24: 351-357.

16. Poulter LW, Campbell DA, Munro CD, Butcher RG. The quantification of HLA-DR expression on human cells using immunocytochemistry. J Immunol Methods 1987; 98: 227-234.

17. Janossy G, Bofill M, Poulter LW. Two colour immunofluorescence analysis of the lymphoid system with monoclonal antibodies. In: Polak J, Van Noorden S, eds. Immunocytochemistry Today, Bristol, J. Wright \& Sons, 1986; p. 438.

18. Cockcroft DW, Killian DN, Mellon JJA, Hargreave FE. Bronchial reactivity to inhaled histamine: a method and clinical survey. Clin Allergy 1977; 7: 235-243.

19. Poulter LW, Norris A, Power C, et al. T-cell dominated inflammatory reactions in the bronchioles of asymptomatic asthmatics are also present in the nasal mucosa. Postgrad Med J 1991; 67: 747-753.

20. Power C, Sreenan S, Hurson B, Burke C, Poulter LW. The distribution of immunocompetent cells in the bronchial wall of clinically healthy subjects exhibiting bronchial hyperresponsiveness. Thorax 1993; 48: 1125-1129.

21. Burke C, Power C, Norris A, Schmekel B, Condez A, Poulter LW. Lung function and immunopathological changes after inhaled corticosteroid therapy in asthma. Eur Respir J 1992; 5: 73-79.

22. Bienenstock J. Bronchus-associated lymphoid tissue. In: Bienenstock J, ed. Immunology of the Lung and Upper Respiratory Tract. New York, McGraw Hill, 1984; pp. 96-117.

23. Thepen T, McMenamin C, Girn B, Kraal G, Holt PG. Regulation of $\operatorname{IgE}$ production in pre-sensitized animals in vivo: elimination of alveolar macrophages selectively increases $\mathrm{IgE}$ responses to inhaled allergen. Clin Exp Allergy 1992; 22: 1107-1114.

24. Holt PG, Oliver J, Bilyk N, et al. Downregulation of the antigen presenting cell function(s) of pulmonary dendritic cells in vivo by resident alveolar macrophages. J Exp Med 1993; 17: 397-407.

25. Pozzi E, DeRose V, Rennard SI, Fabbri LM. Guidelines and recommendations for the clinical use of bronchoalveolar lavage in chronic bronchitis and emphysema. Eur Respir Rev 1992; 2: 121-124.

26. Campbell DA, DuBois RM, Poulter LW. Immunocompetent cells in bronchoalveolar lavage reflect the cell populations in transbronchial biopsies in pulmonary sarcoidosis. Am Rev Respir Dis 1985; 132: 1300. 